\title{
DEFORMATION MICROSTRUCTURES OF BARRE GRANITE: AN OPTICAL, SEM AND TEM STUDY
}

\author{
A. SCHEDL ', A.K. KRONENBERG ${ }^{2}$ and J. TULLIS ${ }^{3}$ \\ ${ }^{I}$ Department of Geological Sciences, University of Michigan, Ann Arbor, MI 48109 (U.S.A.) \\ 2 U.S. Geological Survey, 345 Middlefield Road, Menlo Park, CA 94025 (U.S.A.) \\ 3 Department of Geological Sciences, Brown University, Providence, RI 02912 (U.S.A.)
}

(Received February 4, 1985; revised version accepted June 27, 1985)

\begin{abstract}
Schedl, A., Kronenberg, A.K. and Tullis, J., 1986. Deformation microstructures of Barre granite: an optical, SEM and TEM study. Tectonophysics, 122: 149-164.

New scanning electron microscope techniques have been developed for characterizing ductile deformation microstructures in felsic rocks. In addition, the thermomechanical history of the macroscopically undeformed Barre granite (Vermont, U.S.A.) has been reconstructed based on examination of deformation microstructures using optical microscopy, scanning electron microscopy, and transmission electron microscopy. The microstructures reveal three distinct events: (1) a low-stress, high-temperature event that produced subgrains in feldspars, and subgrains and recrystallized grains in quartz; (2) a high-stress, low-temperature event that produced a high dislocation density in quartz and feldspars; and (3) a lowest-temperature event that produced cracks, oriented primarily along cleavage planes in feldspars, and parallel to the macroscopic rift in quartz. The first two events are believed to reflect various stages in the intrusion and cooling history of the pluton. and the last may be related to the last stages of cooling, or to later tectonism.
\end{abstract}

\section{INTRODUCTION}

Within the past decade there has been considerable interest in the possibility of utilizing dislocation densities, subgrain sizes, and recrystallized grain sizes in rocks as paleopiezometers to infer stress magnitudes (Ball, 1957; Lutton and Sellars, 1969; Twiss, 1977; Mercier et al., 1977; Weathers et al., 1979; Christie and Ord, 1980). The success of such studies depends in part on one's ability to characterize these deformation microstructures. Dislocation substructures in naturally deformed rocks are usually studied with the transmission electron microscope (TEM) at magnifications $>5000 \times$ (e.g., Wenk et al., 1976); however, many geologists do not have access to such an instrument, and the scale of observation is so small that it is difficult to determine a meaningful average. Low dislocation densities can be 
observed in etched samples using optical microscopy (e.g., Patel et al., 1965; Wegner and Christie, 1983), but its low resolution limits such studies to relatively undeformed grains. The scanning electron microscope (SEM) bridges the gap in scale between the optical microscope and the TEM. Although the SEM has been used in the investigation of cracks (e.g., Kranz, 1979), it has only rarely been used to study ductile deformation microstructures (Ball and White, 1977).

One purpose of this study was to develop easy-to-use SEM techniques for characterizing deformation microstructures of felsic rocks, and to test the technique by comparison with TEM and optical observations. Quartz, microcline, and plagioclase grains in samples of Barre granite (Vermont. U.S.A.) were examined, and a deformation history was constructed for this granite which is consistent with stress variations during cooling of an intrusion.

\section{GEOLOGIC SETTING}

The Barre granite is a post-deformational Acadian granite. It intrudes discordantly through the lower Devonian Giles and Waits River Formations, which were metamorphosed to biotite grade and intensely deformed during the Acadian orogeny (White and Jahns, 1950; Albee, 1968), between 385 and 410 Ma B.P. (Zartman et al., 1970; Naylor, 1971; Pajari et al., 1974; Dalmeyer et al., 1982). The Barre granite is corundum-normative and has a high initial strontium ratio, 0.712 , suggesting it is an S-type granite, generated by the partial melting of sediments (Naylor, 1971; Chappel and White, 1974). Rb/Sr dating yields an intrusion age of $350 \mathrm{Ma} \mathrm{B.P.,} \mathrm{and} \mathrm{K/Ar}$ on biotite yields a cooling age of 345 Ma B.P. (Faul et al., 1963; Zartman et al., 1970; Naylor, 1971). The granite lacks a visible foliation, but possesses a well-developed vertical rift (plane of easiest splitting) striking $\mathrm{N} 30^{\circ} \mathrm{E}$, sub-parallel to the regional foliation of $\mathrm{N} 20^{\circ} \mathrm{E}$ (Douglass and Voight, 1969; Engelder et al., 1977).

\section{SAMPLE PREPARATION}

All observations were made on a single $0.15 \mathrm{~m}$ block of Barre granite collected by T. Nichols from the Wetmore Quarry, Barre, Vermont. The composition of this rock is $25 \%$ quartz, $20 \%$ microcline, $35 \%$ plagioclase $\left(\mathrm{An}_{11}\right), 9 \%$ muscovite, $9 \%$ biotite, and $2 \%$ accessories (Chayes, 1952). The quartz and feldspar grains are roughly equant, with an average diameter of $1-2 \mathrm{~mm}$.

Three mutually perpendicular thin sections were made for optical examination; these are parallel to the rift (nearly vertical), the lift or grain (nearly horizontal), and the hardway. From these thin sections, $3 \mathrm{~mm}$ circular samples were removed for TEM study. These samples were ion-milled (using procedures described in Kronenberg and Shelton, 1980), and examined in bright field using a JEM-7 instrument operating at $100 \mathrm{KV}$.

The SEM method utilized is not a standard technique, and is described in detail 
in the Appendix. Briefly, it involves careful polishing and sequential etching, using techniques modified from Wegner et al. (1978) and Wegner and Christie (1983). Observations on feldspar grains were made after an initial etching step, and then samples were re-etched before making observations on quartz grains.

\section{RESULTS}

\section{Optical observations}

Although the Barre granite appears completely undeformed in hand sample, optical observations show evidence of both ductile and brittle deformation. Some quartz grains show sub-basal deformation lamellae, and most show moderate to extreme undulatory extinction; grain boundaries are sutured, and subgrains and recrystallized grains (50-70 $\mu \mathrm{m}$ diameter) are developed on the concave side of curved grain boundaries (Fig. 1A). Douglass and Voight (1969) measured 60 quartz $c$-axes in a sample of Barre granite, and found a maximum density parallel to the hardway pole, and a subsidiary maximum parallel to the rift pole. We have measured $130 c$-axes from three perpendicular sections and find them to be concentrated in a rough great circle girdle within the hardway plane, with the greatest maximum sub-parallel to the pole of the plane of the lift. There is no detectable grain (or phase shape) flattening or mica alignment, so the total strain responsible for all these deformation microstructures is probably small, $<10 \%$.

The quartz grains also show evidence of brittle deformation. Open microcracks and planes of fluid inclusions, probably indicative of healed cracks, are common in orientations sub-parallel to the rift, and less common in orientations subparallel to the lift, as noted previously by Douglass and Voight (1969). These cracks cut across subgrains and recrystallized grains (Fig. 1B).

The feldspars show much less optical evidence for ductile deformation. A slight undulatory extinction is present in the plagioclase grains, but none is present in the microcline. Both feldspars show grain-scale microcracking, but unlike quartz, the orientations of the cracks are related to the crystallography of the grains (twin and cleavage planes) rather than a regional pattern. Cracks in plagioclase grains are sometimes filled with mica, while cracks in microcline grains tend to be filled with quartz or calcite.

\section{TEM observations}

TEM observations of quartz grains show a uniform distribution of dislocations (Fig. 2A), having a density of $(7.6 \pm 3.4) \times 10^{12} / \mathrm{m}^{2}$. TEM also shows subgrains and subgrain walls; an average subgrain diameter could not be determined, however, due to the small field of view. Recrystallized grains were observed, but again could not be measured because of the field of view. There is a higher density of subgrains close 

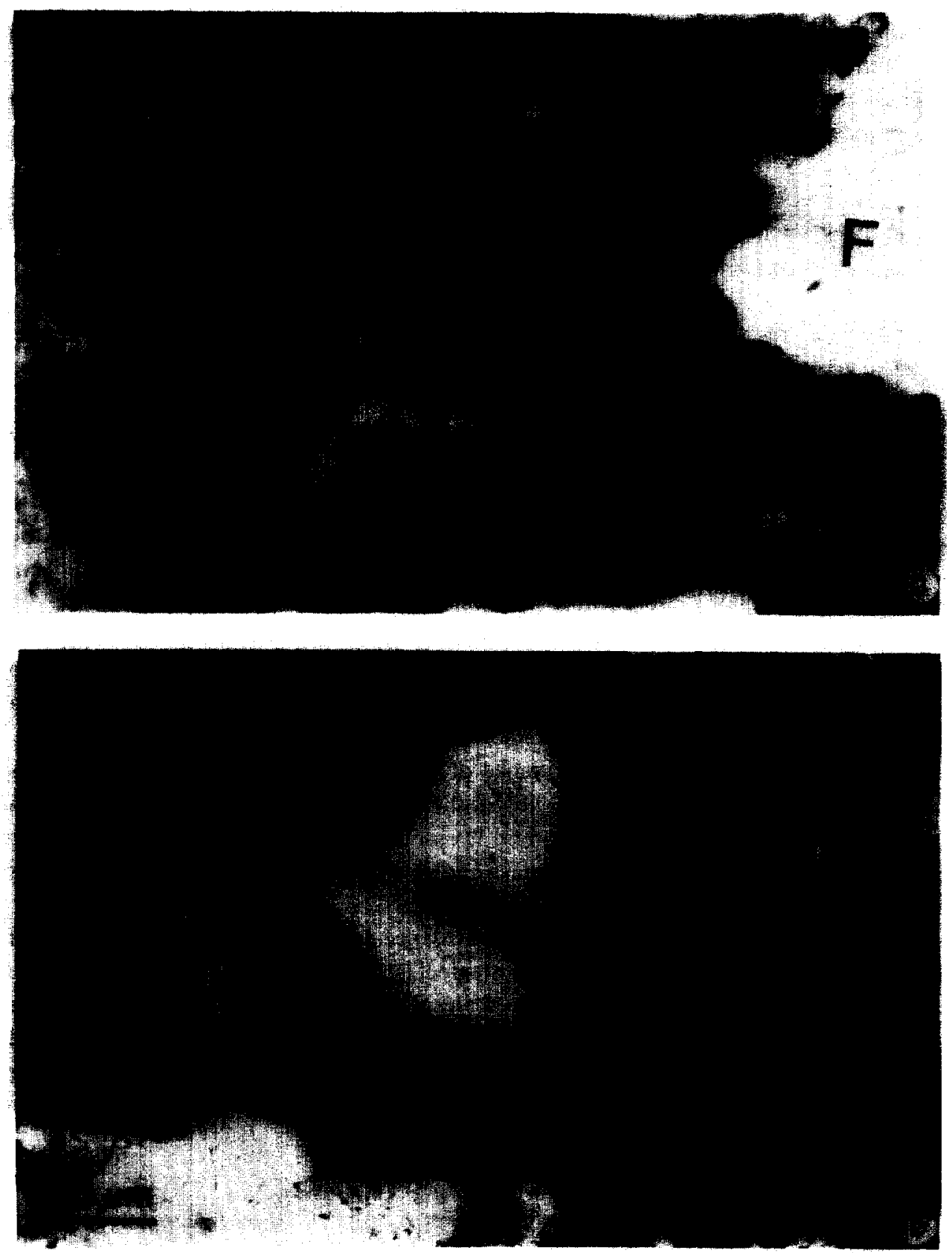

Fig. 1. a. Microfractures ( $f r)$ parallel to rift cutting across subgrains in quartz $(Q z)$. Note the lack of microcracks in feldspar $(F)$. Magnification $35 \times$. b. Recrystallization of quartz $(r q)$ and subgrain formation in plagioclase (sf) adjacent to a grain boundary. (Quartz $-Q z$ and plagioclase-- $F$.) Magnification $130 \times$. 
to grain boundaries, voids and inclusions. The cracks observed in TEM are straight and sharp, and show no association with dislocation microstructures.

Plagioclase grains (Fig. 3A) show high densities of tangled dislocations along twin and subgrains boundaries, but in between these boundaries the density is much lower, $(1.9 \pm 1.1) \times 10^{12} / \mathrm{m}^{2}$. Subgrains were noted in some areas, and extremely fine peristerite lamellae were observed to be best developed in these regions. Microcracks

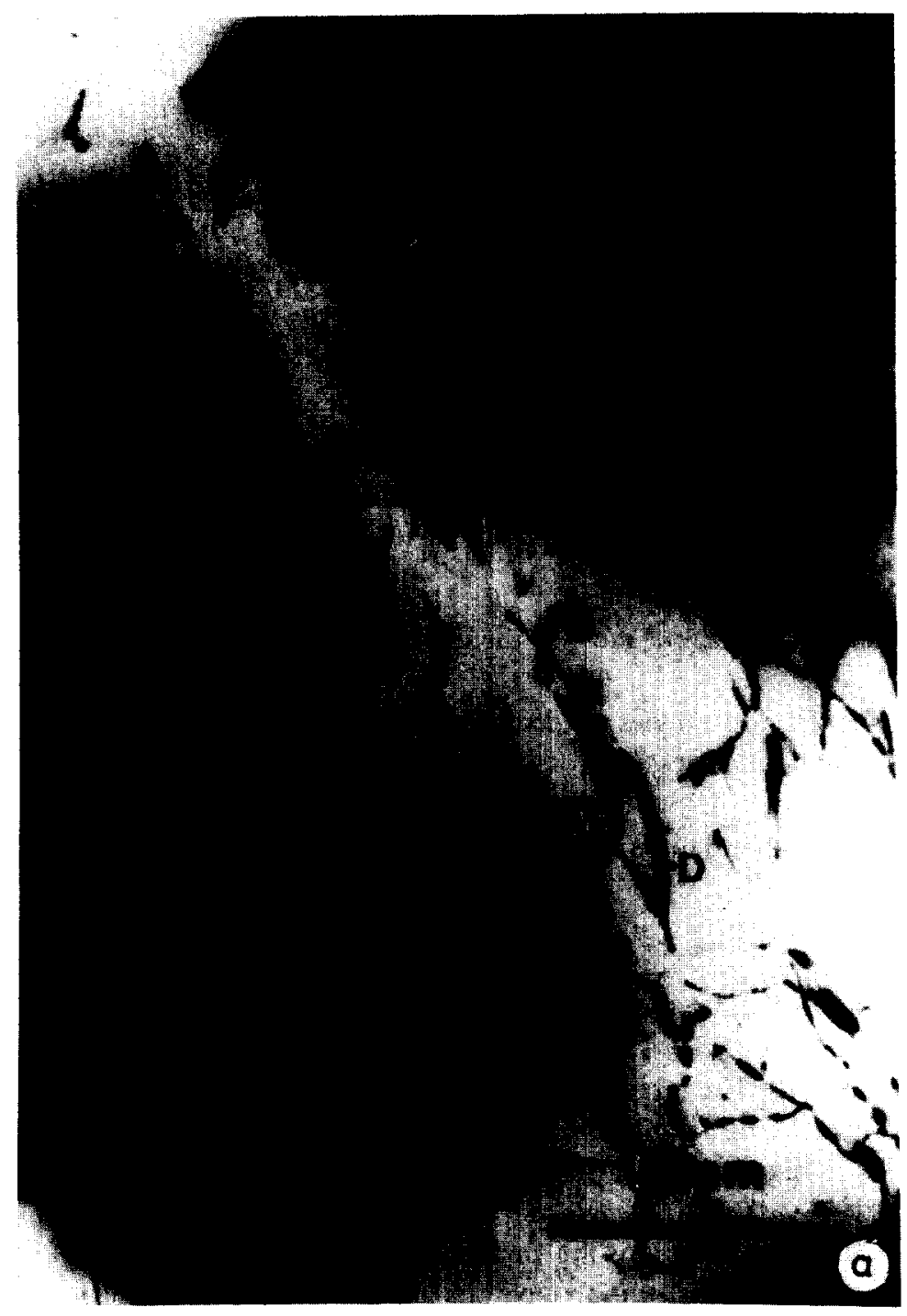

Fig. 2a. A TEM bright field image of dislocations $(D)$ in quartz. Note the uniform distribution of dislocations. 




Fig. 2 b. Oblique view of dislocation etch pits in quarts as seen in SEM.

are more numerous than in quartz, but most of them are parallel to cleavage or twin planes.

Microcline grains show dense tangles of dislocations along and adjacent to the albite and pericline twin boundaries (Fig. 4A); away from these boundaries the density is much lower, about $4.7 \times 10^{11} / \mathrm{m}^{2}$. Occasional subgrains are present. Microcracks are moderately abundant, and most are aligned parallel to cleavage.

\section{SEM observations}

The dislocation density in quartz grains as determined from etch pits on multiple plates measured with SEM is $(5.5 \pm 1.2) \times 10^{12} / \mathrm{m}^{2}$ (Fig. 2B), in good agreement with the TEM determinations. The larger field of view in the SEM shows that there is no association between the dislocation arrays and the microcracks in the quartz grains, It also allows us to make measurements of subgrain sizes (using the intercept method of Pickering, 1976) on multiple plates; average subgrain size is $160 \mu \mathrm{m}$, however, near grain boundaries subgrains are smaller, $50-70 \mu \mathrm{m}$.

In plagioclase grains (Fig. 3B), dislocation etch pits are not as easily recognized as in quartz, because they are obscured by other microstructures. Nevertheless, the mean free dislocation density measured with SEM $(1.6 \pm 0.5) \times 10^{12} / \mathrm{m}^{2}$, is in good 
agreement with TEM values. Dislocation arrays in subgrain boundaries are more difficult to observe than in TEM, because they are obscured by other microstructures. For this reason subgrain size could not be estimated from SEM plates. Fine peristerite lamellae are visible, because the compositional variations cause differential etching (Fig. 3C).

In microcline grains, it is difficult to distinguish albite and pericline twins, and the dense dislocation tangles along the twin boundaries are only suggested by the overlapping etch pits (Fig. 4B). However, the measured free dislocation density of $3.3 \times 10^{11} / \mathrm{m}^{2}$ is in good agreement with that determined from TEM.

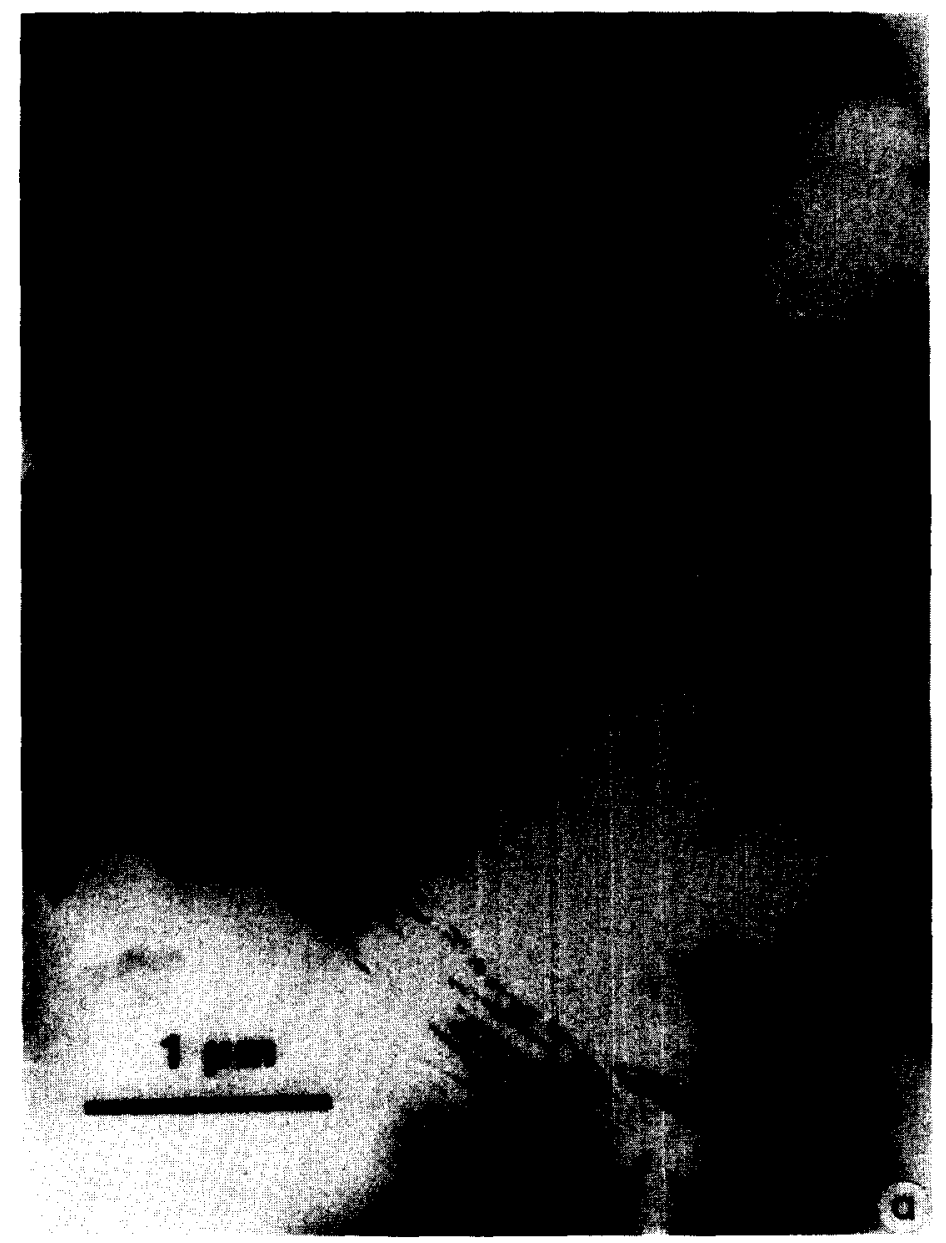

Fig. 3. a. TEM bright field image of dislocations $(D)$ in plagioclase. The lines running across the image at a $75^{\circ}$ angle are peristerite exsolution lamellae $(P)$. b. SEM image of dislocation $(D)$ etch pits intersecting the surface of the plagioclase grains at an oblique angle. c. SEM image of peristerite exsolution lamellae $(P)$ in plagioclase. 



Fig. 3b, c. For legend see p. 155. 
DISCUSSION

\section{Comparison of optical, SEM and TEM observations}

This study shows that it is possible to use the SEM to characterize accurately dislocation densities higher than previously achieved, up to $10^{13} / \mathrm{m}^{2}$ in quartz. This is a great improvement over the maximum of $10^{10} / \mathrm{m}^{2}$ using optical methods (Wegner and Christie, 1983). Since dislocation densities in naturally deformed rocks rarely exceed $10^{13} / \mathrm{m}^{2}$, the SEM can be applied to tectonites deformed under most geologic conditions (Christie and Ord, 1980; Kohlstedt and Weathers, 1980).

Compared to TEM, SEM observations have both disadvantages and advantages. The three-dimensional geometries of dislocation structures cannot be determined using SEM, because observations are restricted to etched surfaces. In addition, SEM does not provide crystallographic information except for crystal faces with low Miller-Bravais indices and well-developed etch pits (Wegner and Christie, 1983). For high dislocation densities, overlapping etch pits cause SEM estimates to be lower than TEM estimates; however, the standard deviation for SEM estimates is smaller, because of the larger areas examined. The chief advantages of SEM are its greater ease of use, and the large areas that can be examined. This latter factor is especially important given the inhomogeneities in deformation microstructures between differently oriented grains and grains of different phases in a deformed polyphase aggregate (e.g., Tullis and Yund, 1977).

\section{Interpretation of Barre granite deformation history}

The cross-cutting relationships of the optical deformation microstructures preserved in the quartz and feldspar grains of the Barre granite indicate an early ductile deformation and a later brittle deformation (evidence for the reverse sequence would not be preserved). Our SEM and TEM observations of these microstructures indicate further details about the thermomechanical history of this rock.

We have utilized published paleopiezometer relations for quartz to make paleostress estimates from our measurements of dislocation density, subgrain size, and recrystallized grain size; there are no published relations for feldspar. The results for quartz are shown in Table 1; the stresses inferred from the dislocation density are much higher (110-170 $\mathrm{MPa}$ ) than those based on the subgrain and recrystallized grain size (10-40 MPa). Based on a comparison with experimentally deformed anorthosite and diabase, the high free dislocation densities in Barre plagioclase are consistent with stresses in the range of 100-200 MPa (Kronenberg and Shelton. 1980). Clearly there are a number of uncertainties associated with the absolute magnitudes of the inferred stresses (e.g., White, 1979); although we cannot evaluate some of these, others we can. We cannot tell what errors there might be in the theoretical and experimental stress-microstructure relations. Errors in the extrapo- 
lation of these relations to the (commonly) lower stresses of naturally deformed rocks may be significant for the low stresses inferred from the subgrain and recrystallized grain sizes. However, the high dislocation densities in quartz are in the same range as experimentally deformed samples (McCormick, 1977).

Even if we cannot be sure of the absolute magnitudes of the inferred stresses, it seems clear that the microstructures record two distinct events. If there has been a single deformation event, there should be evidence for the dislocations organizing $t)$ form incipient subgrain walls in quartz. Instead, there is a relatively uniform distribution of dislocations with a high density. Since the quartz subgrains and

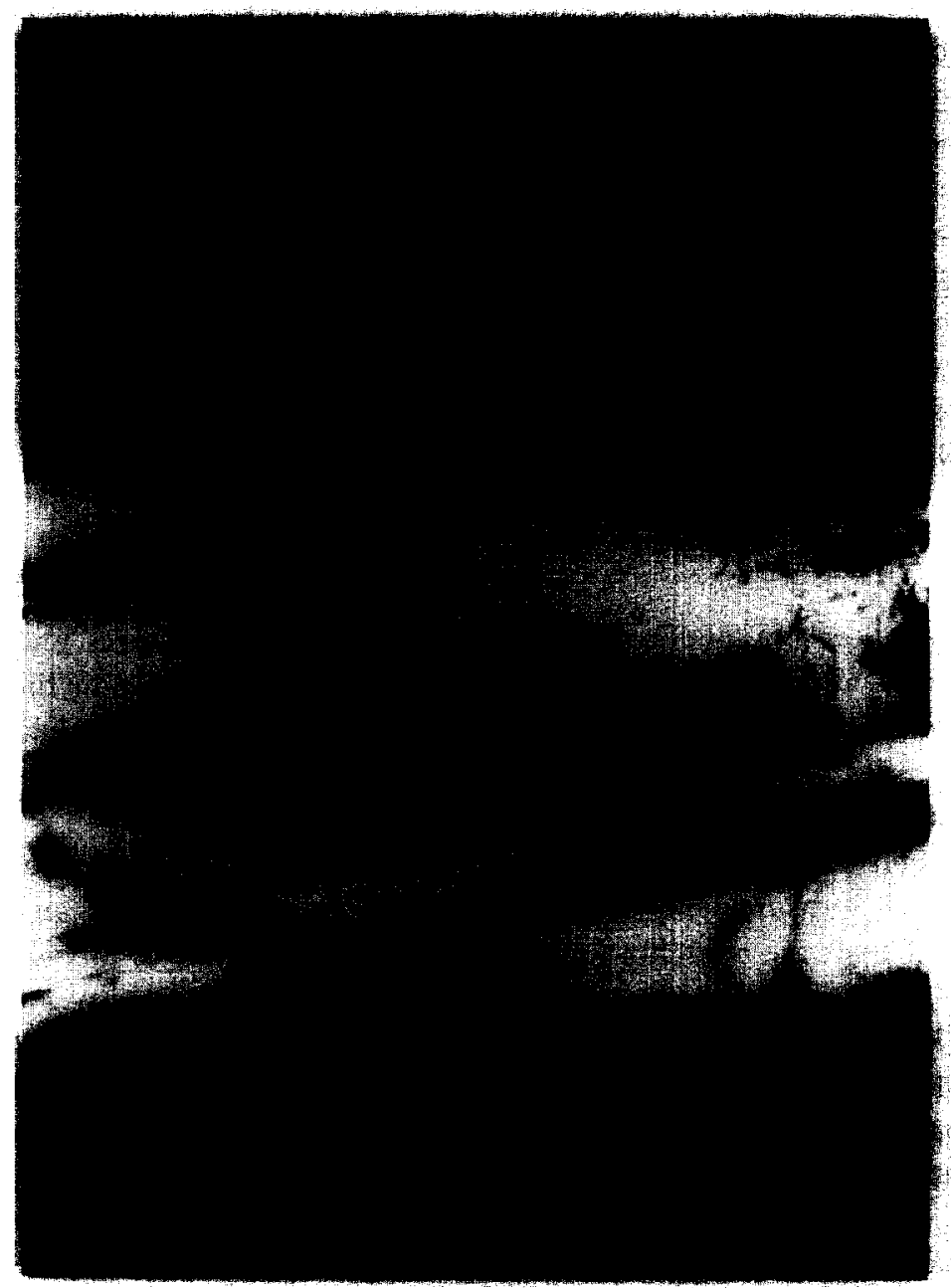

Fig. 4. a. TEM bright field image of dislocation tangles formed along twin boundaries in microcline. $\mathrm{b}$ SEM image of albite and pericline twins in microcline and dislocation pits $(D)$. 


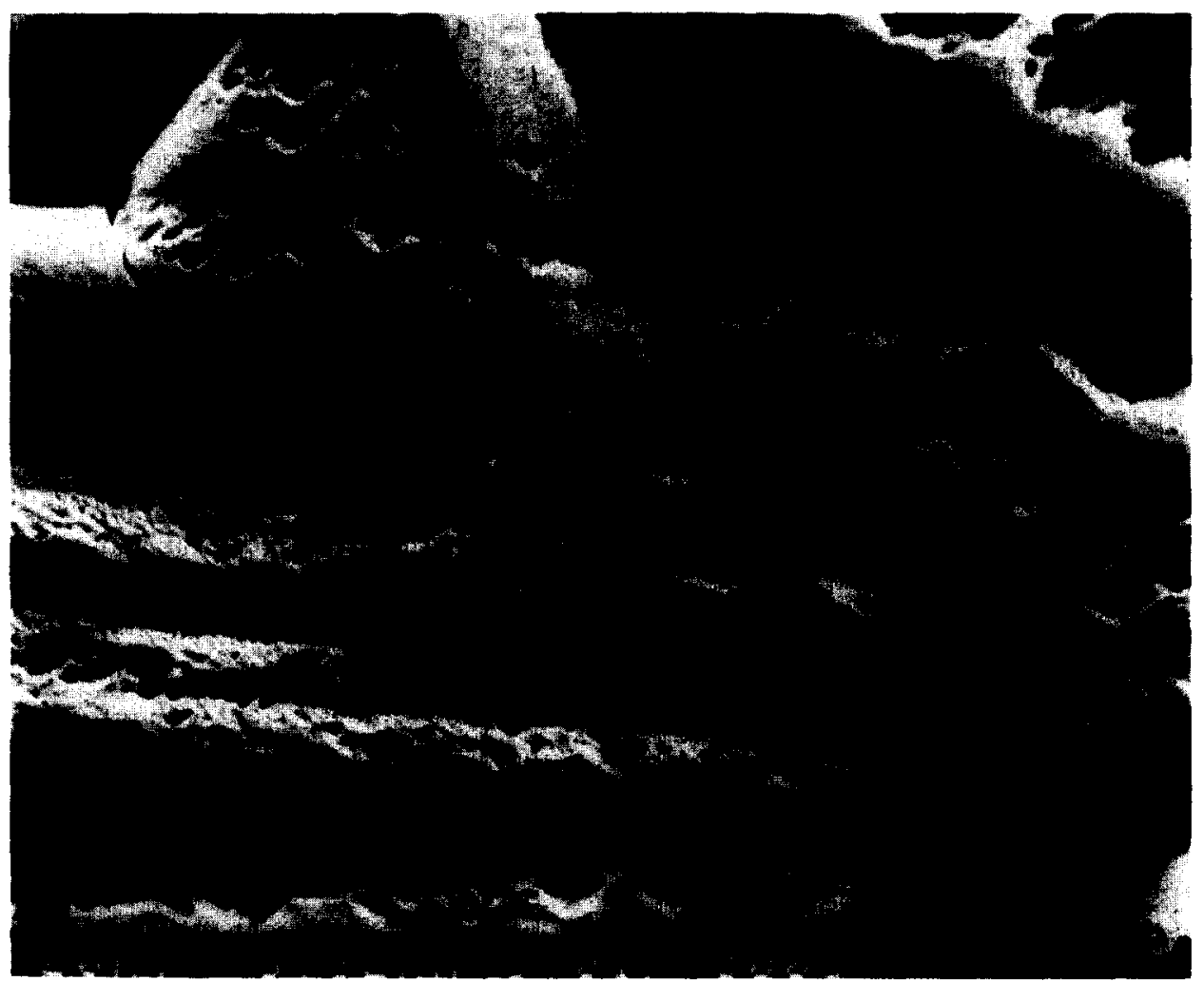

Fig. 4. (continued)

\section{TABLE 1}

Paleostresses inferred from quartz microstructures

\begin{tabular}{llll}
\hline $\begin{array}{l}\text { Microstructural } \\
\text { parameters }\end{array}$ & $\begin{array}{l}\text { Mean } \\
\text { determination }\end{array}$ & $\begin{array}{l}\text { Inferred } \\
\text { deviatoric } \\
\text { stress } \\
(\mathrm{MPa})\end{array}$ & References ${ }^{* *}$ \\
\hline $\begin{array}{l}\text { Subgrain size } \\
\text { Recrystallized grain size }\end{array}$ & $160 \mu \mathrm{m}$ & 12 & $(6)$ \\
& $50-70 \mu \mathrm{m}$ & $14-19$ & $(2)$ \\
Dislocation Density & $6.5 \times 10^{12} / \mathrm{m}^{2}$ & $32-42$ & $(3)$ \\
& & 113 & $(5)$ \\
\hline
\end{tabular}

* Using cited paleopiezometer.

** (1)-McCormick (1977); (2)-Mercier et al. (1977); (3)--Twiss (1977); (4)-Weathers et al. (1979); (5)-Christie et al. (1980); (6)-Kohlstedt and Weathers (1980). 
recrystallized grains are "overprinted" by the high dislocation density, it is most likely that they formed during a lower stress (and presumably higher temperature) event, and that the relatively high dislocation density resulted from a later, higher stress (and presumably lower temperature) event. If the subgrains and recrystallized grains never grew to a steady state size, then they overestimate the actual stress. On the other hand, if the recrystallized grains were annealed after deformation. they underestimate it. The presence of high dislocation densities indicates that deformation continued as temperature fell, suggesting that static annealing was not significant; therefore $10-40 \mathrm{MPa}$ represents a maximum for the earlier event. Similar arguments suggest that the stresses inferred from the dislocation density yield a lower bound on the stresses for the later, lower temperature event.

The early low-stress event which produced subgrains in the feldspar (and possibly peristerite; see Marshall and Wilson, 1976), and subgrains and recrystallized grains in the quartz probably involved temperatures of at least $300^{\circ} \mathrm{C}$ (Wilson, 1973: Voll. 1976; Tullis and Yund, 1977). The Barre granite was presumably intruded after the Acadian deformation and before the Alleghenian orogeny. It therefore seems most likely that the low-stress and higher-temperature event was associated with intrusion. Modeling studies suggest that there are a number of ways in which differential stresses may be generated during the crystallization of an intrusion by (e.g.. Savage. 1978; Knapp and Norton, 1981; Marsh, 1982): (1) buoyancy differences between the solidified and the partially molten granite; (2) volume changes during melt solidification; and (3) exsolution of a fluid phase from the melt. We believe that the subgrains in the feldspars and quartz, and recrystallized grains in the quartz reflect a high-temperature, low stress deformation in the latter stages of intrusion when the granite was partially solidified. The differences in the response of yuart\% and feldspars to deformation is consistent with previous observations on experimentally and naturally deformed samples (Tullis and Yund, 1977; Carter et al.. 1981; Tullis and $Y$ und, 1985).

After solidification of an intrusion, temperature gradients and differential thermal contraction can also generate differential stresses. Numerical modeling suggests that the latter process could produce stresses as high as 100-200 MPa (Savage, 1978: Knapp and Norton, 1981). We believe that the high dislocation densities in the quartz and feldspars of the Barre granite probably reflect a later, low-temperature and high-stress deformation, due to thermal contraction in the fully crystallized and colder, stronger rock. It should be emphasized that the finite strain accomplished by this stress is small, $<1 \%$.

The high dislocation densities could alternatively be associated with stresses generated during uplift (White, 1979). However, the presence of andalusite and sillimanite in the contact aureole indicates pressures less than $400 \mathrm{MPa}$ at the time of intrusion (Holdaway, 1971). In addition, temperature was $<450^{\circ} \mathrm{C}$ because the country rock only reached biotite grade. Given these observations and the lower temperature limit over which dislocations are mobile in quartz $\left(\sim 250-300^{\circ} \mathrm{C}\right)$ and 
plagioclase $\left(-400^{\circ} \mathrm{C}\right)$, we feel that the Barre granite was on the low $T$-low $P$ side of the brittle-ductile transition during most of its uplift history (Tullis and Yund, 1977; White and White, 1983, Schedl, 1984). Thus, any stress relaxation during uplift probably occurred by brittle processes. In fact, healed and open microcracks are abundant and overprint the other microstructures. The cracks in the quartz grains are parallel to the macroscopic rift, as noted in other granites (e.g., Peng and Johnson, 1972). Quartz has an anomalously high and anisotropic coefficient of thermal contraction, so cooling accompanying uplift would be expected to cause cracking (Savage, 1978). Presumably these extension cracks would align normal to the least compressive stress if the quartz were randomly oriented (Peng and Johnson, 1972; Solberg, 1975). However, the quartz in the Barre granite has a preferred orientation, with the maximum concentration of $c$ axes subparallel to the pole to the grain or lift. The thermal contraction of quartz is significantly greater $\perp c$ than $\| c$, so the orientation of the rift cracks is roughly consistent with the c-axis preferred orientation. On the other hand, the orientation of the cracks may have resulted from Alleghenian and/or Triassic deformation.

\section{CONCLUSIONS}

Polishing and etching techniques have been developed for the SEM which allow accurate characterization of deformation microstructures generated in quartz and feldspar over most of the range of natural deformation. The SEM permits more detailed observations than is possible with the optical microscope, and much larger areas of observation than is possible with the TEM.

A combination of optical, SEM and TEM observations of deformation microstructures in the Barre granite reveals details of its thermomechanical history. This granite was intruded after the Acadian orogeny; regional, hand sample and thin section observations indicate that finite strain was at most a few percent. However, microstructures in the feldspars and especially the quartz indicate the following:

(a) An early high-temperature, low-stress event which produced subgrains in the feldspars and subgrains and recrystallized grains in the quartz due to deformation accompanying the last stages of intrusion.

(b) A later, low-temperature, high-stress event produced a uniform high dislocation density in quartz and high free dislocation densities in plagioclase, probably the result of thermal contraction in a fully crystallized intrusion.

(c) A still later, lower-temperature, low (?) stress event produced aligned microcracks in the quartz due to either thermal contraction and unloading, or later tectonism.

\section{ACKNOWLEDGEMENTS}

We would like to thank T. Nichols for the sample of Barre granite and other support, S. Kirby for helpful discussions, D. Richter for unpublished chemical 
analyses, and M. Wegner for help with the etching techniques. SEM observations were made in the Cell Biology and Anatomy Laboratories at the University of Michigan, and TEM observations were made in the Materials Research Laboratory at Brown University. This research was supported by USGS contract 31898-78, a grant from Shell Oil Company, and a Rackham Dissertation Grant from the University of Michigan.

\section{Appendix: SEM SAMPLE PREPARATION AND OBSERVATION}

Oriented SEM samples were prepared by encapsulating rock chips in $3 \mathrm{~cm}$ epoxy molds, followed by a sequence of surface grinding and polishing using 600 grit silicon carbide (for 30 minutes on a wheel), 600 grit paper (for $20 \mathrm{~min}$ ) and $1 \mu \mathrm{m}$ oil-based diamond paste (for 8-12 hrs on an automatic polishing lap). Samples were cleaned in ethanol using an ultrasonic cleaner and then polished using $0.05 \mu \mathrm{m}$ aluminum oxide for 8-12 hours, again using an automatic polishing lap. This final polishing step removed all visible surface irregularities, including polishing induced cracks, which would be enhanced during the later etching procedure.

The polished surfaces of Barre granite were etched using techniques similar to those of Wegner and Christie (1974, 1983) and Wegner et al. (1978): the technique for etching quartz, however, needed to be modified due to the presence of the feldspars. A serial etching procedure was used, first studying microstructures in the feldspars and then in quartz. Samples were initially etched for $2 \mathrm{~min}$ in etchant \#6 (Wegner et al., 1978), boiled for $5 \mathrm{~min}$ in a complexing solution of citric acid to remove reaction products, rinsed in distilled water and blown dry. The surfaces were then gold-coated and examined using DSI-100 SEM with a $\mathrm{LaBe}_{6}$ filament at $15-25 \mathrm{kV}$. In order to maximize topographic contrast, samples were tilted to $45^{\circ}$. After SEM study of etched feldspar grains, samples were soaked for $2 \mathrm{~min}$ in aqua regia to remove the gold-coating. Feldspar surfaces were unaffected by the aqua regia bath (even in tests up to $6 \mathrm{hrs}$ ). Because (001) faces of feldspars are more readily etched than (010) faces (Wegner et al., 1978), the etching procedure described above was repeated two more times. first using etchant \#6 for $3 \mathrm{~min}$, and then for 5 additional min, and the feldspars re-examined each time.

After SEM study of the feldspars was completed. samples were etched for quartz microstructures. Samples were placed in a concentrated ammonium bifluoride solution for $4 \mathrm{hrs}$, rinsed in distillẹd water and boiled in a complexing citric acid solution for $5 \mathrm{~min}$. Because sub-basal surfaces were not etched by ammonium bifluoride, samples were placed in a bath of etchant $\# 6$ for $1 \mathrm{hr}$. This etching step took significantly more time than that suggested by Wegner and Christie (1983), perhaps because the dissolution of feldspars produced aluminofluro complexes which inhibited etching. Samples were again boiled and rinsed in distilled water, gold-coated, and then examined with the SEM.

\section{REFERENCES}

Albee. A.L., 1968. Metamorphic zones in northern Vermont. In: E. Zen, W.S. White, J.J. Hadley and J.B. Thompson (Editors), Studies of Appalachian Geology. Wiley, New York, pp. 329-341.

Ball, A. and White, S., 1977. An etehing technique for revealing dislociation structures in deformed quartk grains. Tectonophysics, 37: T9-T13.

Ball, C.J., 1957. The flow stress of polycrystalline aluminum. Philos. Mag., Ser. 8: 1011-1017.

Carter, N.L.. Anderson, D.A., Hansen, F.D. and Kranz, R.C., 1981. Creep and creep rupture of granitic rocks. In: N.L. Carter. M. Friedman, J.M. Logan and D.W. Stearns (Editors), Mechanical Behavior of Rocks (the Handin Volume), Am. Geophys. Union, Geophys. Monogr., 24: 61-82.

Chappel, B.W. and White, A.J.R., 1974. Two contrasting granite types. Pac. Geol., 8: 173-174. 
Chayes. F., 1952. Calcalkine granites of New England. Geol.. 60: 207-254.

Christie, J.M. and Ord, A., 1980. Flow stresses from microstructures of mylonites: example and current assessment. J. Geophys. Res., 85: 6253-6262.

Christie, J.M., Ord, A. and Koch, P.S. 1980. Relationship between recrystallized grain size and flow stress in experimentally deformed quartzite. Eos. Trans. Am. Geophys. Union. 61: 377.

Dalmeyer, R.D., Van Breemen, O. and Whitney, J.A., 1982. Rb-Sr whole rock and ${ }^{41} \mathrm{Ar} /{ }^{34} \mathrm{Ar}$ mineral ages of the Hartland Stock, south central Maine: a posi-Acadian representative of the New Hampshire plutonic series, Am. J. Sci., 282: 79-93.

Douglass. P.M. and Voight, B., 1969. Anisotropy of granites: a reflection of microscopic fabric. Geotechnique, 19: 376-398.

Engelder, T., Sbar, M.L. and Kranz, R., 1977. A mechanism for strain relaxation of Barre granite: opening of microfractures. Pure Appl. Geophys., 115: 26-40.

Faul. H., Stern. T.W., Thomas, H.H., and Elmore, P.L.D., 1963. Age of intrusion and metamorphism in the northern Appalachian. Am. J. Sci., 261: 1-19.

Holdaway, M.J., 1971. Stability of andalusite and the aluminum silicate phase diagram. Am. J. Sci.. 271: $97-131$.

Knapp. R.B. and Norton. D., 1981. Preliminary numerical analysis of processes related to magma crystallization and stress evolution in cooling plutonic environments. Am. J. Sci. 281: $35-68$.

Kohlsted1, D.L. and Weathers, M.S., 1980. Deformation-induced microstructures, paleopiezometers and differential stresses in deeply croded fault zones. J. Geophys. Res.. 85: 6269-6285.

Kranz, R.L., 1979. Crack growth and development during creep of Barre granite. Int. J. Rock Mech. Min. Sci., 16: 23-35.

Kronenberg, A.K. and Shelton, G.L., 1980. Deformation microstructures in experimentally deformed Maryland diabase. J. Struct. Geol., 2: 341-354.

Lutton, M.J. and Sellars, C.M.. 1969. Dynamic recrystallization of iron-nickel alloys during high-temperature deformation. Acta Metall., 17: 1033-1043.

Marsh. B.D., 1982. On the mechanics of igneous diapirism, stoping, and zone melting. Am. J. Sci, 282: $808-855$.

Marshali, D.B. and Wilson. C.J.L.. 1976. Recrystallization and peristerite formation in albite. Contrib. Mineral. Petrol., 57: 55-69.

McCormick, J.W., 1977. Transmission electron microscopy of experimentally deformed synthetic quartz, Ph.D. thesis, University of California, Los Angeles, Calif., 177 pp.

Mercier. J.C., Anderson. D.A. and Carter. N.L.. 1977. Stress in the lithosphere: inferences from steady state flow of rocks. Pure Appl. Geophys., 115: 199-226.

Naylor, R.S., 1971. Acadian orogeny: an abrupt and brief event. Science, 72: $558-560$.

Patel, A.R., Bahl, O.P. and Vagu, A.S., 1965. Etching of rhombohedral cleavages of quartz. Acta Crystallogr., 19: 757-758.

Pajari, G.E. Jr., Trembath, R.F., Cormier, R.F. and Fythe, L.R., 1974. The age of Acadian deformation in southwestern New Brunswick. Can. J. Earth Sci., 11: 1309-1313.

Peng, S. and Johnson, A.M., 1972. Crack growth and faulting in cylindrical specimens of Chelmsford granite. Int. J. Rock Mech. Min. Sci., 9: 37-68.

Pickering. F.B., 1976. The basis of quantitative metallography. Metals and Metallurgy Trust for the Inst. of Metallurgical Technicians, London, $38 \mathrm{pp}$.

Savage, W.C., 1978. The development of residual stress in cooling rock bodies. Geophys. Res. Lett., 5: 633-636.

Schedl. A., 1984. The brittle-ductile transition in the Linville Falls fault. Geol. Soc. Am., Abstr. Progr.. 16: 646 .

Solberg, P.H., 1975. The influence of mierocracks on sheet joining in four New England granites. Eos. Trans. Am. Geophys. Union, 56: 44. 
Tullis, J. and Yund. R.A., 1977. Experimental deformation of Westerly granite, J. Cieoph.. Re... 82: $5705-5718$.

Tullis, 1. and Yund, R.A., 1985. Accommodation mechanisms for dislocation creep: Comparson af quartz and feldspar. Eos, Trans. Am. Geophys. Union, 66: 366.

Twiss, R.J., 1977. Theory and applicability of recrystallized grain size paleopiezometry. Pure Appl. Geophys.. 11: 227-244.

Voll, G. 1976. Recrystallization of quartz, biotite, and feldspars from Ersteld to the Leventina Nappe. Swiss Alps, and its geological significance. Schweiz. Mineral. Petrogr. Mitt., 56: 641-647.

Weathers, M.W., Bird, J.M., Cooper, R.F. and Kohlstedt, D.L., 1979. Differential stresses determined from deformation-induced microstructures of the Moine Thrust zone. J. Geophys. Ras.. 84: 7495-7509.

Wegner, M.W. and Christie, J.M. 1974. Preferential etching of terrestrial and lunar olivines. Contrib. Mineral, Petrol, 84: 7495-7509.

Wegner, M.W. and Christie, J.M., 1983. Chemical etching of deformation substructures. Phys. (hem. Miner., $9: 67-78$

Wegner, M.W., Jones, R.E. and Christie, J.M., 1978. Exsolution in terrestrial and lunar plagioclase revealed by etching. Contrib. Mineral. Petrol., 65: 283-291.

Wenk, H.-R. Champness, P.E., Christie, J.M. Cowley, J.M., Heuer, A.H., Thomas, G. and Tighe, N.J., 1976. Electron Microscopy in Mineralogy. Springer, Berlin, 564 pp.

White, J.C. and White, S.H., 1983. Semi-brittle deformation within the Alpine fault zone. New 7ealand. J. Siruct. Geol., 5: $579-590$.

White, S., 1979. Difficulties associated with paleostress estimates. Bull. Mineral. 102: 210^.215.

White, W.S. and Jahns, R.H., 1950. Structure of central and east-central Vermont. 1. Geol., 58: 179-220.

Wilson, C.J.L., 1973. The prograde microfabric in a deformed quartite sequence, Mount Isa. Australia. Tectonophysics, 19: $39 \ldots 1$.

Zartman, R.E., Hurley, P.M., Krueger, H.W. and Giletti, B.J., 1970. A Permian disturbance of K-Ar radiometric ages in New England, its occurrence and cause. Geol. Soc. Am. Bull. 81: 3359-3374. 